\title{
Pozvánka na konferenci Naše společná přítomnost 2016
}

\section{Redakce}

Envigogika 10 (4) - Informace/ Information

Publikováno /Published 31. 12. 2015

DOI: $\underline{10.14712 / 18023061.510}$

\section{Naše společná přítomnost 2016}

\section{Velké naděje, projekty, omyly - snahy o pochopení a ovládnutí pří- rody $v$ minulosti a dnes}

Konference se uskuteční

na Filosofické fakultě UK, Praha 1, nám. Jana Palacha 2, místnost 104 (viz mapa)

ve dnech 31. března (program v češtine) - 1. dubna 2016 (anglická část programu).

Aktuální informace o konferenci a jejím programu najdete zde.

Z kapacitních důvodů je nezbytné se k účasti přihlásit - registrační formulář najdete zde.

\section{Téma konference}

Lidé se $s$ nevypočitatelností prírody snažili vypořádat odjakživa, současně ji ale také svými zásahy $v$ jistém ohledu působili. Odedávna toužili proměnit prostředí, společnost nebo i samotného člověka; pokoušeli se spoutat prírodní síly nebo předcházet nepředvídatelným rizikům. Pokusy o zasahování do prírody nebo manipulaci s lidskou bytostí a vazbami a pouty sociálními či ekonomickými ovšem často pro nepochopení podstatných vnitřních zákonitostí vyzněly (sebe)destruktivně. Hranice mezi tím, co je založeno na snech či pouhé iluzi, a přiznivě působícími plány či procesy, je takřka nerozlišitelná - skutečné přínosy, nebo naopak zásadní rizika se obvykle projeví až po dlouhé době. Kýžený pokrok a nezamýšlená katastrofa jsou často jen dvě strany stejné mince. A tak i v plně odpovědném a vědecky uchopeném vztahu $k$ př́rodě můžeme sledovat poměrně nezřetelnou hranici mezi možným a nemožným, realitou a fikcí, kterou je snadné technickými prostředky pravidelně překračovat.

V tomto smyslu hledáme poučení z minulosti, současně se ale pokoušíme nahlížet do budoucnosti - sledujeme velké (i menší), často utopické plány společenské, technické nebo třeba umělecké. Mapujeme slepé uličky, které lidé v minulosti vyzkoušeli, i ty, do kterých se právě vrhají. Pokládáme to za zpưsob, jak se o vztahu člověka a prírody dozvědět více. Současně si klademe četné otázky, které se nás př́mo dotýkají. $V$ co dnes můžeme doufat, čeho se obávat, kam pravděpodobně směřujeme? A jak (a jakou) o tom podáme zprávu těm, co přijdou po nás - budou žít ve světě postaveném z našich představ a rozhodnutí? 


\section{Organizační tým konference:}

Jana Dlouhá, Centrum pro otázky životního prostředí, Univerzita Karlova v Praze (COžP UK).

Eva Cudlínová, Miloslav Lapka, Jan Vávra, Ekonomická fakulta, Jihočeská univerzita v Českých Budějovicích.

Doubravka Olšáková, Ústav pro soudobé dějiny, Akademie věd České republiky

Zdenka Sokolíčková, Transkulturní komunikace, Pedagogická fakulta Univerzita Hradec Králové.

Filozofická fakulta Univerzity Karlovy v Praze.

Jiří Dlouhý, Společnost pro udržitelný život.

Více o nás se dozvíte také zde.

\section{Abstrakty príspěvků konference}

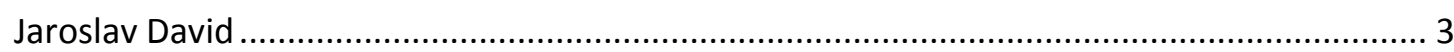

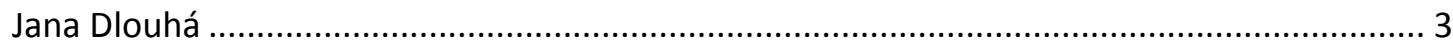

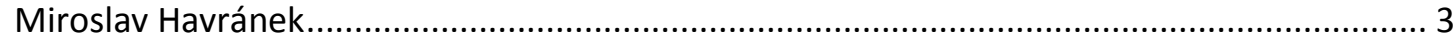

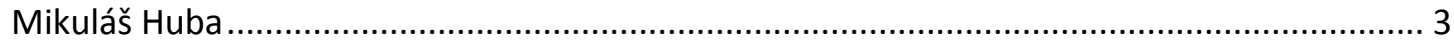

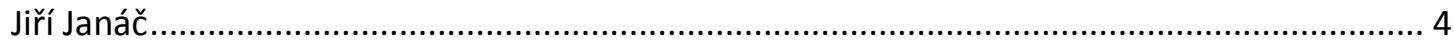

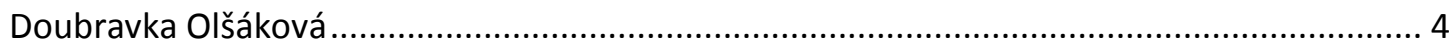

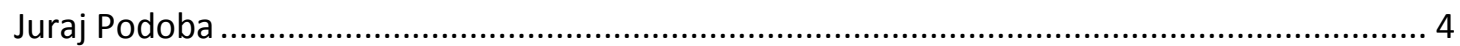

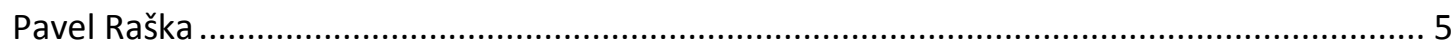

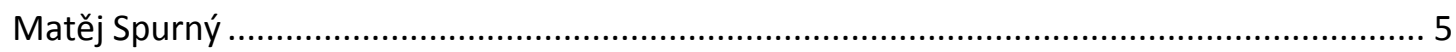

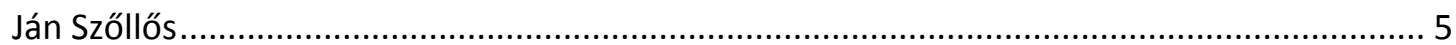

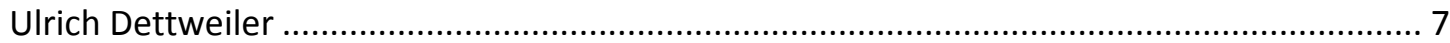

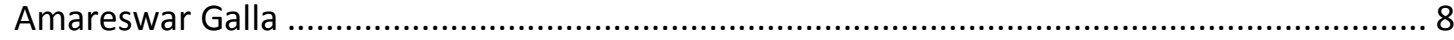

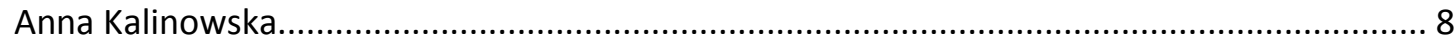

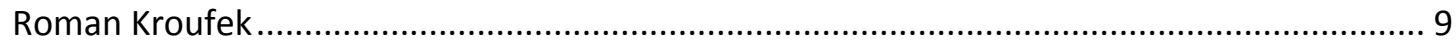

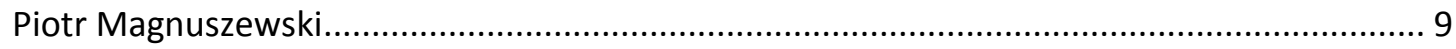

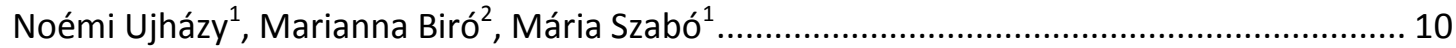




\section{1. března 2016 - česká/slovenská část konference}

Prezentace ( $v$ abecedním pořadí řečníků)

Příroda jako překážka, hodnota i protivník v publicistickém diskurzu o těžbě uhlí a bourání starého Mostu

\section{Jaroslav David}

\section{Katedra českého jazyka Filozofické fakulty Ostravské univerzity}

Př́spěvek se zabývá tématem zániku a přesunu města Most $v$ důsledku rozvoje povrchové těžby uhlí v letech 1964-1982 (1987) a jeho reflexí v dobovém tisku. Dưraz klade nejen na historický kontext, ale především na jazykovou prezentaci tématu $v$ publicistickém diskurzu. Klíčovým tématem jsou proměny vnímání př́rody a krajiny jako hodnoty $\mathrm{i}$ překážky, a to $v$ období od 60 . do 80 . let 20 . století.

Snahy o pochopení a ovládnutí přírody - omyly jsou naším osudem...

\section{Jana Dlouhá}

\section{COŽP UK}

$\mathrm{Na}$ čem je založen vztah člověka a prírody $v$ éře technologického rozvoje? Je tato vazba těsná a (raději) neměnitelná; jak se navenek projevuje? Proč se zabývat konkrétními jevy $v$ jejich přirozeném (historickém, místním) kontextu? A co jsou př́padové studie? Úvodní slovo otevře téma konference a pokusí se odpovědět na tyto a podobné otázky.

\section{Globální megatrendy: naše společná budoucnost}

Miroslav Havránek

\section{COŽP UK}

Příspěvek se zaměří na globální megatrendy a slabé signály, které by mohly změnit jejich směřování. Globální megatrendy jsou určité jevy, které statisticky významně shromažd'ují podobné trendy, což nám může pomoci interpretovat současné dění a pomoci k tomu, abychom se s vyšší jistotou mohli zabývat budoucností. Nicméně tyto trendy, které se utváří po desítky let, nejsou neměnné. Mohou být a často jsou ovlivněny něčím, co se od začátku se zdá irelevantní nebo bezvýznamné. Tyto zárodky změny však často vysílají slabé signály o nových trendech, které se teprve připravují, nebo ohlašují neočekávané nelinearity ve vývoji (jako divoké karty nebo tzv. černé labutě). Př́spěvek bude ilustrovat složitý systém současných megatrendů, spolu s některými identifikovanými slabými signály, které by mohly změnit jejich směřování.

Ochrana prírody a krajiny na Slovensku (straty a nálezy z posledných rokov)

\section{Mikuláš Huba}

\section{PSP Slovenské republiky, Geografický ústav AV SR}

Autor sa problematikou zaoberá paralelne z viacerých pozícií:

ako vedecký pracovník Geografického ústavu SAV, protagonista Spoločnosti pre trvalo udržatel'ný život, dobrovol'ník angažovaný pri oprave pamiatok a údržbe krajiny, pe- 
dagóg externe pôsobiaci na slovenských i českých univerzitách, publicista, aktívny turista a v rokoch 1990-1992 a 2012-2016 i ako poslanec slovenského parlamentu a dvojnásobný predseda jeho environmentálneho výboru. To mu umožňuje vnímat', hodnotit' a interpretovat́ danú problematiku širokospektrálne a komplexne. Z takéhoto pohladu vývoj prírody, krajiny a životného prostredia a vztáahu $\mathrm{k}$ týmto fenoménom priniesol $v$ slovenských podmienkach viac negatív (straty), ako pozitív (nálezy). Príspevok hovorí o tom, ako sa dívat' na veci realisticky, a zároveň nachádzat $v$ zdanlivo beznádejnom vývoji aj zdroje nádeje.

\section{Inženýrský sen o průplavu DOL - plánování velkého technického projektu ve dvacátém století}

\section{Jiř́í Janáč}

\section{Ústav pro soudobé dějiny AV ČR}

Projekt průplavu DOL, kontinuálně přepracovávaný od počátku dvacátého století, do značné míry zachycuje dějiny moderního vodního hospodářství v Česku. Předkládaný přispěvek se soustředí na problémy kontinuity a diskontinuity v plánování průplavu. Jedná se tak o prípadovou studii proměn odborného diskursu o vodě jako součásti prírodního prostředí a zásadního předpokladu života společnosti, ale také o studii vztahu vodohospodářských inženýrů a státní moci v průběhu dvacátého století.

\section{"Poručíme větru, dešti....!" Mezi komunistickou mytologií a envi- ronmentální politikou před 1989}

\section{Doubravka Olšáková}

\section{Ústav pro soudobé dějinv AV ČR}

Příspěvek se na příkladu stalinského plánu přetvoření přírody zaměři na proměnu vztahu př́rody a člověka v 50.-60. letech. Nakolik byly velké plány přetvoření přírody skutečně důsledkem plánů artificiální změny společenského klimatu a nakolik jen pouhou touhou a iluzí komunistické moci ukázat svou nadřazenost nad přírodními jevy? Příspěvek se také zaměři na klíčové milníky a okamžiky proměny tohoto vztahu v komunistickém Československu.

\section{„A já vám hovorím: na vrchu Manýne budú rást banány!" Komunistické sociálne inžinierstvo a transformácia kultúrnej kra- jiny na slovenskom vidieku}

\section{Juraj Podoba}

\section{Fakulta sociálnych a ekonomických vied, Univerzita Komenského v Bratislave}

Sociálne inžinierstvo sa stalo neoddelitel'nou súčastóou komunistického modernizačného projektu. Jeho deklarovaným ciel'om bol "pokrok". Komunistický experiment bol pôvodne utopickým projektom urbánnych politických extrémistov, popri vidieckej šlachte a (malo)buržoázii v podstate namierený proti rol'níctvu. Až na malé výnimky sa tento projekt realizoval $v$ zaostalých agrárnych krajinách s neefektívnym pol'nohospodárstvom. Nástrojom na jeho zefektívnenie, a zároveň na zlomenie rol'níctva bola socialistická kolektivizácia pol'nohospodárstva. $V$ podmienkach slovenského vidieka druhej polovice 20 . storočia bola kolektivizácia spojená $\mathrm{s}$ "politikou zbližovania mesta a dediny". Čo v praxi znamenalo mechanický prenos (malo)mestských kultúrnych fenoménov do konzervatívneho vidieckeho prostredia. 
Ciel'om príspevku je analýza dopadov komunistického rozvojového projektu na charakter sídelnej a kultúrnej krajiny $\mathrm{v}$ prostredí slovenského vidieka. Autor vychádza $z$ dlhodobého etnografického výskumu osídlenia, architektúry a bývania $v$ troch modelových vidieckych sídlach počas druhej polovice osemdesiatych rokov 20. storočia, kontinuálne pokračujúceho $v$ nasledujúcich desat́ročiach.

\section{Úvahy nad "rizikovou společností": viděno historickou geografií Pavel Raška}

\section{Katedra geografie, Přírodovědecká fakulta, Univerzita J. E. Purkyně}

Výchozím bodem přednášky je Giddensovo (Giddens 1999) pojetí rizikové společnosti a jejích charakteristik, zvláště pak aspektu konce prírody (the end of nature) a konce tradice (the end of tradition). $\mathrm{V}$ rámci přednášky bude tato teorie aplikována na problematiku přírodních rizik a způsobů, jakými se s nimi společnost vyrovnávala a vyrovnává. $\mathrm{Na}$ základě několika aktuálních př́padových studií z Česka, rámovaných zahraničními studie$\mathrm{mi}$, bude poukázáno na problematiku mytizace $\mathrm{v}$ diskursu o př́rodních rizicích. Ten je charakteristický kontradiktorním pojetím tradiční a moderní kultury zmírňování následků přírodních pohrom. Tyto kontradikce jsou patrné zvláště $v$ diskursu o šetrnosti vůči prírodě, možnostech ovlivnění dopadů prírodních pohrom a v kulturní reprezentaci příčin těchto pohrom. Př́spěvek naopak poukáže na významné podobnosti mezi tradičními a moderními společnosti, a tudíž i na skutečnost, že zmíněné kontradiktorní pojetí do jisté míry brání tematizaci a rozvinutí některých otázek efektivity redukce rizik $v$ současnosti.

\section{Proměny diskurzu o životním prostředí ve státně socialistickém Československu: př́pad likvidace starého Mostu}

\section{Matěj Spurný}

\section{Ústav pro soudobé dějiny AV ČR}

Konec padesátých let a především léta šedesátá jsou ve většině průmyslových zemí spojeny s proměnou myšlení o životním prostředí a historickém dědictví. To se pochopitelně týká i státně socialistických zemí. Poté, co odezněl poválečný industriální patos vrcholící $v$ éře stalinského budovatelského nadšení, můžeme $v$ českém prostředí sledovat dominantní technokratické vztahování se ke světu, které klade důraz na exaktní vědecké poznání a racionální plánování, ale zároveň také ostrou kritiku tohoto redukování života na měřitelné veličiny. Jedním ze symbolických center této společenské debaty je i otázka životního prostředí v severních Čechách, včetně svébytné diskuze o záchraně či likvidaci historického města Most. Na príkladu severních Čech můžeme sledovat proměny a roli environmentální kritiky i během normalizačního období, na jehož konci pak sehraje zásadní roli v procesu delegitimizace panství KSČ.

\section{Ovládat' alebo spravovat' - dilemy krest́anstva a krestáanov vo vztáahu k prírode"}

\section{Ján Szőllős}

\section{STUŽ SR}

Náboženstvo a viera mali a ešte aj v súčasnosti majú velký vplyv na formovanie vzt́ahu človeka ako jednotlivca a aj ludskej spoločnosti k prírode. Cielom príspevku je približit vývoj filozofického a teologického myslenia a s ním spojenej praxe "západnej" 
spoločnosti založenej prevažne na judeo-krestáanských hodnotách od koncepcie ovládania, panovania nad stvorenstvom (prírodou) ku postoju založenom na princípe spravovania stvoreného sveta. Pokúsime sa hl'adat' aj odpoved' na otázku, či má súčasné krestanstvo potenciál prispiet́ $\mathrm{k}$ transformácii myslenia a konania človeka a spoločnosti smerom k udržatel'nému životu. 


\section{April, 1 $^{\text {st }}, 2016$ - English part of the conference}

Presentations (in alphabetical order of speakers)

\section{Our common present: Playing with dimensions in the space-for- time approach to understand climate change in science education Ulrich Dettweiler}

\section{Technical University of Munchen, Department of Sports and Health Sciences}

Global climate change influences ecosystems across the world. Alpine plant communities in particular have already experienced serious impacts and will continue to do so as climate change continues. From a didactic point of view, specifically phenophases of plants, i.e. their seasonal developmental status in relation to weather and micro-climatic conditions, are relatively easy to observe and allow for conclusions on climate change.

In our didactic concept, we sensitize secondary school pupils to the effects of climate change. We take the pupils on an eco-climatological expedition into the Berchtesgaden National Park during a one-week residential program, and "research weeks" at the Student Research Center Berchtesgadener Land. The "research weeks" combine social learning, personal development, and ecological knowledge on a regional level in an educational concept in order to achieve sustainable learning effects in "global learning".

During the "research weeks", the pupils are split in groups of three to four and become experts in plant phenology, meteorology and micro-climatology, glaciology, and pedology. On the first two days of the course, each group prepares for the expedition in the lab, i.e. getting to know their specific indicator plant, learning about weather parameters and local weather history, or the geological conditions in the area. Then the pupils set out for a 2 or 3-day expedition and collect their data along a transection of about 1,000m elevation. It is their responsibility to organize their research protocol. Each group is assigned one facilitator - an accompanying teacher, a student, or scientific staff from the Student Research Center - in order to empower the pupils to carry out the complex field work and document their findings.

Back in the valley, the pupils analyze their findings and share their knowledge with the others in the form of a group puzzle. During the reflection and de-briefing phase, the pupils gain a deeper understanding of their own findings, connect different pieces of information, and thus reach a deeper understanding of the complexity of weather/microclimate and plant phenology. Finally, we transfer the local findings to the global level. The spacefor-time approach thus serves as a didactic tool. The difference in average temperature of approximately 2 degrees from the valley to the high mountain area over an elevation of $1,000 \mathrm{~m}$, which was experienced and measured during the expedition by the pupils, can be used as a model for global warming and be projected into the future.

Evaluative research has shown that this didactic concept is suitable to significantly enhance the pupils' learning motivational behavior opposed to learning inside the classroom. We suggest implementing more expeditionary learning programs in local areas with respect to education and learning for climate change adaption and resilience 


\title{
Curating Environmental Landscapes and Ecomuseums
}

\section{Amareswar Galla}

\author{
Honorary Professor, Global Change Institute, The University of Queensland, \\ Brisbane, Australia; Curator, Amaravati Ancient Town \& Visiting Professor \& In- \\ ternational Curator, Don Bosco Centre for Indigenous Cultures, Shillong, India; \\ International Institute for the Inclusive museum.
}

The process and outcomes of the UN Paris Climate Conference (COP21) in December 2015 underline clearly that climate change is culturally induced. In this context the nonduality of culture and nature needs to be recognised as a colonial legacy knowledge system. Decolonisation of the discourse of environmentalism and heritage studies is critical for appreciating, understanding and acting on the COP 21 Action Plan through developing deep ecology models for integrated environmental management. This presentation brings together certain salient features for developing such models based on the speaker's first hand 'fingers in the dirt' work over the past three decades curating environmental landscapes and ecomuseums in the Marine Environment of Ha Long Bay, Vietnam; Riverine environments in Hoi An, Vietnam and Amaravati, India; and the Darjeeling mountainous environment in the Himalayas. It is the argument that when local communities benefit from developmental initiatives they become actors and animateurs in making changes environmentally sustainable, a non-negotiable must for minimising climate impacts. The conclusion will be substantiated from case studies on evidence based, quantitative and qualitative, benefit sharing in the volume produced by the speaker for Cambridge University Press and UNESCO in 2012/2013 (World Heritage: Benefits Beyond Borders) as part of the process for the drafting and adopting the Sustainable Development Goals in 2015 September to guide the UN post-2015 Development Agenda.

\section{How to whitewash the "black character"- environmental and cul- tural education contra false stereotypes which rule the relation- ship between man and wolves}

\section{Anna Kalinowska}

\section{University of Warsaw, The University Centre for Environmental Studies and Sustainable Development}

Wolves have always been seen as man's big enemy. As an enemy they were exterminated in most areas in Poland. Extermination of wolves can be listed as one of the unsuccessful human interventions in nature as wolves play a key role in keeping the forest ecosystem healthy. Scientists are just beginning to fully understand the positive ripple effect that wolves have on ecosystems. Though wolves once nearly disappeared from most forests, they have returned to Poland today. Since 1995 wolves have been a protected species but it is difficult to "whitewash" the perception of them in the public mind. This dark reputation of the wolf as an cruel beast is strengthened by myths, legends and fairytales. Programmes of education considering these cultural aspects will be presented as an example of good practice in public education supporting conservation of the wolf population in Poland. 


\section{The nature-man relationship as a research topic}

\section{Roman Kroufek}

\section{Pedagogical Faculty, Jan Evangelista Purkyně University, Ústí nad Labem}

The nature-man relationship affects not only the degree to which we behave responsibly towards our environment but also a number of personality qualities, including personal well-being and happiness. The paper discusses the history of the perception of the nature-man relationship, its current trends and the importance of this relationship from a pedagogical point of view. It works with constructs like nature relatedness, connectedness to nature, the inclusion of nature in self, love and care for nature and explains the differences between them as well as some psychometric indicators from Czech Republic. It focuses on the quantitative approach to the nature-man measurement and highlights the possibilities and limits of the use of different research tools.

\section{Expectations and failures to control Nature - a gaming perspecti-} ve.

\section{Piotr Magnuszewski}

\section{Centre for Systems Solutions, Wrocław, Poland}

Many failed projects to control nature often result from inadequate appreciation of the diversity of ways decisions are made at all levels of society. Policy resistance was the frequent, tragic result, reversing initial successes with policy failure. Analysis and understanding of complex policy issues is often hampered by the high costs of gathering data about how various members of society actually think and decide about such issues. Policy makers must often invest years to gain experience critical to managing systems that change and evolve without undertaking real risk. This raises the question: Can we lower the costs of learning through experience?

A variety of new gaming methodologies that combine computational models and the participation of real actors has emerged to fill this gap. They allow participants to analyze how problems emerge in complex systems and where points of policy intervention may lie because they are experienced as something that feels real, more information is retained, learning is faster, and an intuition is gained into how to make real decisions and improve policies.

This session will provide a simulation gaming perspective on the main conference theme. Using connected real life stories and related simulation games, the session will demonstrate the potential of games to create opportunities for deep reflection by its participants. With the capacity to "compress time and space" that the games provide, it is possible to gain further insight into a better understanding of the impacts of human interventions to transform Nature. 


\title{
Perceptions of a drying landscape - two case studies from the Du- na-Tisza interfluve region, Hungary
}

\author{
Noémi Ujházy ${ }^{1}$, Marianna Biró ${ }^{2}$, Mária Szabó $^{1}$
}

1. Eotvos Loránd University, Dept. of Landscape and Environmental Geography; 2. Hungarian Academy of Sciences, Ecological Centre

In this paper two methodologically different case studies will be presented from a the Danube-Tisza interfluve, Great Hungarian Plain region of Hungary which has seen many anthropogenic transformations over the centuries. One of the most significant changes in the $20^{\text {th }}$ century was the drainage of the inland wetlands and decline of the groundwater level. This significantly affected local living conditions and the state of natural wetland habitats too. The first case study will be a historical analysis of the polarized social perception of a drainage channel crossing the study territory (the Main Channel of the Danube Valley), which was poignantly labelled the "Cursed Channel". The second case study will be a more contemporary one, concerning the recent perception of landscape changes. Local farmers and nature conservationists were interviewed about how they perceive landscape changes, including the transformation of wetland habitats. Through a comparison of these two case studies, perceptions of environmental change, risk and vulnerability will be discussed. 